\title{
ЗАСТОСУВАННЯ ІГРОВИХ ФОРМ У ПРОЦЕСІ ВИВЧЕННЯ ДИСЦИПЛІНИ «КОНТРОЛЬ І РЕВІЗІЯ У БЮДЖЕТНИХ ТА ФІНАНСОВИХ УСТАНОВАХ»
}

\author{
Рецензент - доктор економічних наук, професор В. Я. Плаксієнко
}

\begin{abstract}
Впровадження інтерактивних методик у викладанні фахових дисциилін дає змогу докорінно змінити ставлення до об'єкта навчання, перетворивши його на суб'єкт. Студент стає співавтором лекиії, семінарського заняття тошо. У статті досліджено порядок застосування інтерактивних форм навчання для виховання у студентів таких якостей майбутнього фахівия, щзо сприяли б виконанню поставлених перед ними завдань, формування комплексу аналітичних, прогностичних, інновачійних $i$ організаційнокомунікативних здібностей.
\end{abstract}

Ключові слова: контроль, завдання, методи$\kappa a$, інтерактивні форми, виховання, навчання, студенти, якості, вміння.

Постановка проблеми. Використання коштів державного (місцевого) бюджету передбачає перевірку та здійснення контрольних заходів щодо ефективності й цільового їх використання, збереження майна, забезпечення виконання бюджетного процесу. Для виконання визначених завдань необхідно організувати і проводити контрольноревізійну роботу на різних рівнях виконання бюджету.

Призначення навчальної дисципліни «Контроль і ревізія у бюджетних та фінансових установах» полягає у формуванні у студентів знань із питань організації контролю та проведення перевірок фінансово-господарської діяльності організацій усіх форм власності, контролю й ревізії організацій та установ, які отримують державне фінансування.

Студенти повинні ознайомитися із заходами, спрямованими на боротьбу з безгосподарністю, розкраданням, зловживанням службовим становищем посадових осіб установ та організацій, видами відповідальності, що випливають із даних порушень.

Аналіз останніх досліджень і публікацій, у яких започатковано розв'язання проблеми. Актуальні питання організації контрольних процедур розглядаються вченими та практиками України. Особливу увагу на організацію і забезпечення контролю звертають В. А. Александров, П. Г. Германчук, Л. В. Гуцаленко, Т. Г. Мельник та інші. Не менш актуальними є дослідження 3 питань застосування в навчанні інтерактивних методик, що проводяться вченими відомих дослідницьких установ, серед яких О. Д. Витвицька, В. А. Кручек, Л. Г. Вікторова, 3. А. Абасов, В. І. Сафіулін.

Мета і завдання дослідження. Метою статті $\epsilon$ дослідження впровадження інтерактивних освітніх технологій у навчальний процес для підвищення його якості, висвітлення досвіду та особливостей їх впровадження на сучасному етапі.

Завдання - висвітлення практичного досвіду застосування ігрових форм навчання студентів.

Результати дослідження. Основна мета та завдання вивчення дисципліни «Контроль і ревізія у бюджетних та фінансових установах»:

- навчити студента розуміти необхідність та порядок застосування контролюючих заходів у ході перевірки господарських операцій, перевіряти правильність складання фінансової звітності у відповідності з діючими законодавчими актами та методологічними засадами бухгалтерського обліку, розуміти особливості ведення обліку у бюджетних установах, контролювати процес організації обліку господарських операцій таким чином, щоб він забезпечував користувача достовірною, повною і правдивою інформацією про діяльність бюджетної установи;

- виховати у студента такі якості контролюючого працівника, які б забезпечили виконання тих завдань, що стоять перед ним;

- навчити майбутнього фахівця розуміти всю систему контрольно-ревізійної роботи, порядок складання планів ревізій;

- навчити майбутнього фахівця контрольноревізійної служби узагальнювати результати ревізії, перевірки чи моніторингу;

- формування комплексу аналітичних, прогностичних, інноваційних i організаційнокомунікативних здібностей, необхідних майбутньому фахівцю з обліку, контролю та ревізії у бюджетних установах.

Сьогодні вже неможливо викладати дисципліни традиційно, коли у центрі навчального процесу знаходиться викладач, а студенти мовчки 


\section{ЕКОНОМІКА}

сприймають матеріал, слухають пояснення на лекціях або звітують на семінарських і практичних заняттях, виконують контрольні завдання, складають заліки, іспити, одержують оцінки за ті знання і навики, які набули у процесі навчання. Впровадження інтерактивних методик у викладанні фахових дисциплін дає змогу докорінно змінити ставлення до об'єкта навчання, перетворивши його на суб'єкт. Студент стає співавтором лекції, семінарського заняття тощо.

До проведення практичного заняття 3 дисципліни «Контроль і ревізія у бюджетних та фінансових установах» у ігровій формі проводиться підготовка викладача спільно зі студентами. Проведення ділової гри є якби підсумковим, модульним контролем отриманих знань. Студенти до проведення гри розглянули основні поняття, форми, методи та прийоми організації й проведення контролю, володіють знаннями з організації обліку в бюджетних установах.

Проведення практичних занять у формі гри може здійснюватися за різними темами. Ми розглянемо організацію найактуальніших: «До нас іде ревізор» та «Проведення інвентаризації коштів і матеріальних цінностей».

«До нас іде ревізор». Студенти поділяються на дві групи - фінансові контролери та представники бюджетної установи. Кожна з груп визначає напрями та методи своєї діяльності, в результаті чого буде розглянуто: планування контрольної та ревізійної роботи, порядок оформлення документів, підготовка до проведення контрольних заходів та початок проведення ревізії.

Студенти 3 групи фінансових контролерів розподіляють обов'язки та проводять поетапну підготовку до проведення ревізіі:

- готують наказ на проведення ревізії, програму та робочий план;

- організація повідомлення, оформлення документів на проведення;

- вихід в установу;

- проведення ревізії фінансово-господарської діяльності.

Студенти - представники бюджетної установи - розробляють документи з організації контролю в установі, оформлення документів за результатами контрольних заходів, організації та проведення ревізії в установі.

«Проведення інвентаризачї коштів та матеріальних ияінностей». Студенти поділяються на дві групи - фінансові контролери та представники бюджетної установи. Кожна з груп визначає напрями та методи своєї діяльності, в результаті чого буде розглянуто: порядок організації проведення інвентаризації, оформлення документів, визначення результатів та розмірів завданих збитків, відображення в обліку.

Студенти - представники бюджетної установи - визначають шляхи підготовки до проведення інвентаризації:

- готують проект наказу про проведення інвентаризації;

- визначають склад інвентаризаційних комісій;

- визначають терміни, об'єкти та місця проведення інвентаризації.

Студенти з групи фінансових контролерів визначають об' єкти й місця проведення інвентаризації, розподіляють обов'язки та проводять інвентаризацію майна в навчальній аудиторії.

За підсумками проведеної роботи студенти спільно:

- оформляють результати проведення інвентаризації;

- розглядають на засіданні інвентаризаційної комісії та приймають рішення у разі виявлення нестач чи лишків матеріальних або грошових цінностей;

- беруть пояснення причин відхилень у матеріально-відповідальних осіб;

- визначають розмір завданих збитків;

- відображають в обліку результати інвентаризації.

Практичні заняття служать для навчання аналітико-розрахунковим методам і розвитку навичок їх застосування. Таким чином, головною метою практичних занять $є$ засвоєння методу використання теорії, придбання професійних умінь, а також практичних умінь, необхідних для вивчення подальших дисциплін. Студенти залучаються до активної, вмотивованої, самостійної навчальної діяльності. Пропонована форма організації навчального процесу дозволяє поєднати педагогічне управління 3 власною ініціативою i самостійністю студентів, активно використовуючи наявні знання та досвід студентів.

Найбільш емоційно привабливими і професійно необхідними в інноваційному навчанні $\epsilon$ імітаційні активні методи, які поділяються на неігрові (аналіз конкретних ситуацій, імітаційні вправи, індивідуальний тренінг) та ігрові (ділові ігри, розігрування ролей, ігрове проектування). Саме вони є найбільш суттєвими у професійній направленості навчального процесу юридичного ВН3, бо є важливим засобом орієнтування студента на такі цінності, як краще засвоєння майбутньої спеціальності, оволодіння професійною майстерністю, створення нових, більш цінних, алгоритмів діяльності.

Педагогічна готовність до інноваційної діяльності забезпечується: особистісним і професій- 


\section{EKOHOMIKA}

ним вдосконаленням педагога, роботою зі своїм внутрішнім «Я», педагогічної вірою в неповторну індивідуальність студента, бажанням допомагати йому в розвитку [2].

Висновок. Отже, до сучасних методів організації навчального процесу та інноваційних підходів активізації пізнавальних здібностей студентів облікових спеціальностей із дисципліни

\section{БІБЛІОГРАФІЯ}

1. Бех І. Д. Готовність педагога до інноваційної діяльності [Електронний ресурс]. - Режим доступу. - http://www.nbuv.gov.ua
«Контроль і ревізія у бюджетних та фінансових установах» належать: розгляд практичних варіативних ситуацій (методика кейсів), проведення ділових ігор, самонавчання за допомогою науково-методичних комплексів за кредитномодульною системою організації навчального процесу.

2. Омельченко Л. Н. Формирование инновационного потенциала педагогов [Электронный ресурс]. - Режим доступа. - http://sibac.info/12179. 